\title{
UPAYA MENUMBUHKAN KESADARAN MASYARAKAT DALAM MENJAGA KEBERSIHAN LINGKUNGAN MELALUI PENGELOLAAN BANK SAMPAH
}

\author{
Faisal Arif Rahmadani \\ ${ }^{1}$ Program Studi Pendidikan Masyarakat IKIP Siliwangi, Cimahi, Jawa Barat, Indonesia \\ ${ }^{1}$ blackcrow0827@gmail.com
}

Received: Juli, 2020; Accepted: September, 2020

\begin{abstract}
Garbage is a problem in society that is very difficult to overcome and becomes a scourge in the community, as happened in West Bnadung Regency. Various attempts have been made to solve this problem, one of which is through the waste bank. The waste bank is an environmental management program designed by the government. However, this certainly will not work without help from the community. Karang Taruna is one of the reforming agents in developing the community's ability to keep the environment clean. The involvement of Karang Taruna is not only in order to raise public awareness of the environment, but also to become an important part of managing the Sukamaju Sejahtera waste bank located in Sukamaju Village, Padalarang District, West Bandung Regency. In addition, the involvement of this youth organization is also expected to help the community to better maintain its environment so that it is free from waste problems in the surrounding environment, it is also hoped that it can help the government to reduce the number of waste problems in West Bandung Regency.
\end{abstract}

Key words: Waste bank, Youth organization, environmental cleanliness.

\begin{abstract}
Abstrak
Sampah adalah masalah dalam masyarakat yang sangat sulit untuk diatasi dan menjadi suatu momok dalam lingkungan masyarakat, seperti yang terjadi di Kabupaten Bnadung Barat. Berbagai upaya telah dilakukan untuk memecahkan masalah tersebut, salah satunya dengan melalui bank sampah. Bank sampah adalah suatu proram peengelolaan lingkungan yang di rancang oleh pemerintah. Namun hal ini tentu tidak akan berjalan tanpa bantuan dari masyarakat. Karang taruna menjadi salah satu agen pembaharu dalam mengembangkan kemampuan masyarakat dalam menjaga kebersihan lingkungan. Keterlibatan karang taruna tidak hanya dalam rangka menumbuhkan kesadaran masyarakat akan lingkungan, namun juga menjadi bagian penting dalam mengelola bank sampah Sukamaju sejahtera yang berada di Desa Sukamaju, Kecamatan Padalarang, Kabupaten Bandung Barat. Selain itu keterlibatan karang taruna ini juga diharapkan dapat membantu masyarakat untuk lebih menjaga lingkunganya agar terbebas dari masalah sampah di lingkungan sekitarnya, juga diharapkan dapat membantu pemerintah untuk menekan jumlah masalah sampah yang ada di Kabupaten Bandung Barat. Kata kunci: Bank sampah, Karang taruna, Kebersihan lingkungan.
\end{abstract}

How to Cite: Rahmadani. (2020). Upaya Menumbuhkan Kesadaran Masyarakat Dalam Menjaga Kebersihan Lingkungan Melalui Pengelolaan Bank Sampah. Comm-Edu (Community Education Journal) 3 (3), 261-270.

\section{PENDAHULUAN}

Sampah adalah masalah dalam masyarakat yang sangat sulit untuk diatasi. Sampah menjadi suatu momok dalam kehidupan masyarakat. Masih banyak sampah - sampah yang berserakan, tidak hanya di selokan - selokan, jalan raya, bahkan sungai hingga laut pun tercemar akibat permasalahan yang ditimbulkan oleh sampah. Dengan demikian sampah telah menjadi masalah 
262 Rahmadani, Upaya Menumbuhkan Kesadaran Masyarakat Dalam Menjaga Kebersihan Lingkungan Melalui Pengelolaan Bank Sampah

yang teramat penting yang juga harus mendapatkan perhatian juga penanganan yang lebih intensif dari berbagai pihak baik dalam masyarakat maupun pemerintah.

Menurut Kementrian Lingkungan Hidup (2012) setiap harinya masyarakat di Indonesia menghasilkan 490.000 ton per hari atau dengan total sebanyak 178.850.000 ton sampah dalam waktu satu tahunya. Masalah pencemaran lingkungan ini di dasarkan atas kurangnya pemahaman dan kesadaran masyarakat serta kurangnya sosialisasi dari pemerintah maupun pihak - pihak terkait akan pentingnya menjaga kebersihan lingkungan dalam upaya peengelolaan masalah lingkungan dan juga pemberdayaan masyarakat.

Masalah sampah hampir sebagian besar terjadi di daerah perkotaan, dimana perkotaan inilah menjadi pusat dari kegiatan industri, urbanisasi juga kegiatan sehari - hari yang terjadi di kota. Seperti Kabupaten Bandung Barat contohnya, permasalahan yang timbul di Kabupaten Bandung Barat ini terutama di picu karena besarnya volume sampah, selain itu hal ini diperparah oleh keterbatasan lahan sebagai tempat pembuangan akhir yang diikuti jumlah pertumbuha dan urbanisasi penduduk yang cukup tinggi, dimana hal inilah di tunjang pula dengan adanya teknis pengelolaan sampah yang masih konvensional.

Banyak sampah - sampah yang tertinggal kemudian dibiarkan saja tanpa adanya kesadaran untuk mengolahnya sama sekali sehingga dapat menyebabkan kerusakan lingkungan, atau menurunya tingkat kebersihan di dalam masyarakat sehingga lingkungan pun tercemar, tidak enak di pandang, kumuh, kotor, dan kerap menimbulkan penyakit. Dan apabila ada yang peduli akan pentingnya menjaga kebersihan lingkungan di Kabupaten Bandung Barat ini pun masih menggunakan cara - cara yang bias dibilang sangat tradisional, seperti dibakar, dikubur, atau bahkan dibuang kesungai, hal ini tentu saja dapat mengurangi jumlah dari volume sampah tersebut namun belum tentu dapat mengurangi jumlah kerusakan yang ditimbulkan dengan menggunakan cara - cara tersebut, karna dengan cara tersebut efek samping yang dapat ditimbulkan adalah berupa pencemaran tanah, udara, dan juga air.

Maka dari itu pemerintah Kabupaten Bandung Barat pun melakukan upaya yang dirasa dapat mengurangi jumlah volume sampah serta mengurangi kerusakan yang timbul dari cara tradisional diatas yakni melalui upaya penanggulangan sampah dengan melalui kegiatan memfasilitasi sarana umum dengan tempat sampah, melakukan kegiatan pendekatan terhadap masyarakat berupa sosialisasi yang dapat mengajarkan masyarakat dalam menjaga kebersihan lingkungan dengan cara memilah sampah yang baik dan benar agar masyarakat dapat menumbuhkan kesadaran akan pentingnya menjaga lingkungan, dan juga melalui program bank sampah.

Hal tersebut dilandasi oleh Peraturan Mentri Negara Lingkungan Hidup Repulik Indonesia Nomor 13 Tahun 2012 Pasal 1 yang menjelaskan bahwa: Kegiatan Reduse, Reuse, dan Recycle atau membatasi sampah, guna ulang sampah dan daur ulang sampah yang selanjutnya disebut kegiatan 3R adalah segala aktivitas yang mampu mengurangi segala sesuatu yang dapat menimbulkan sampah, kegiatan penggunaan kembali sampah yang layak pakai untuk fungsi yang sama atau fungsi yang lain, dan kegiatan mengolah sampah untuk dijadikan produk baru. Dan bank sampah adalah tempat pemilahan dan pengumpulan sampah yang dapat di daur ulang dan atau diguna ulang yang memiliki nilai ekonomi. Pasal 2 menjelaskan bahwa: Peraturan Menteri ini bertujuan untuk memberikan pedoman kepada pelaksana kegiatan 3R melalui bank sampah. Kegiatan 3R melalui bank sampah sebagaimana dimaksud pada ayat (1) dilaksanakan terhadap sampah rumah tangga dan sampah sejenis sampah rumah tangga. 
Tentu saja program bank sampah ini tidak bias lepas terhadap pemberdayaan masyarakat. Dimana pemberdayaan merupakan usaha untuk memperbaiki kehidupan masyarakat dengan cara memberikan pemahaman serta pengendalian tentang kekuatan sosail, ekonomi dan juga politik. Konsep pemberdayaan ini juga tidak terlepas dari pendidikan non-formal, dalam system system pendidikan nasional, pendidikan non-formal pada pasal 26 ayat 3 menjelaskan bahwa pendidikan non-formal ini meliputi diantara lain: Pendidikan kecakapan hidup atau life skill, Pendidikan kepemudaan dan lain - lain yang ditujukan untuk mengembangkan kemampuan peserta didik. Dan salah satu contoh bank sampah yang dirasa dapat dan mampu memberdayakan masyarakat sekitr Kabupaten Bandung Barat ini adalah bank sampah Sukamaju Sejahtera yang terletak di Desa Sukamaju RW 06, Kecamatan Padalarang, Kabupaten Bandung Barat.

Desa Sukamaju merupakan kawasan pemukiman warga yang terletak di kawasan perkomplekan Baloper, Kecamatan Padalarang, Kabupaten Bandung Barat. Dimana masyarakat yang berada di Desa Sukamaju ini memiliki keanekaragaman suku, agama dan juga jenis mata pencaharian yang berbeda - beda pula. Banyaknya masyarakat dan juga aktifitas dalam menghasilkan limbah inilah yang sering menyebabkan banyaknya timbunan sampah di sekitar jalan maupun di sekitar pemukiman warga, hal inilah yang juga dapat merusak keindahan dan kebersihan lingkungan sehingga menyebabkan lingkungan sekitar Desa Sukamaju ini menjadi kumuh, kotor dan tidak enak dipandang. Hal ini pun semakin diperparah dengan rendahnya kesadaran pemahaman dan ilmu akan pentingnya menjaga kebersihan lingkungan juga bagaimana memilah - memilah sampah. Sehingga tidak heran di musim penghujan Desa Sukamaju ini selalu mengalami banjir akibat penyumbatan sampah di tiap tiap selokan di sekitar pemukiman warga. Selain itu banyaknya keluhan yang terjadi akibat masyarakat yang membuang sampah secara sembarangan ini yaitu megenai dampak atau bau dari sampah yang dibuang secara sembarangan, selain itu dampak yang dapat menjadikan sarang penyakit seperti Demam Berdarah Dengue atau DBD.

Dari hal tersebutlah Ketua RW 06 yang di bantu oleh para pengurus juga anggota Karang Taruna RW 06 beserta para pengurus dan juga anggota dari PKH atau Program Keluarga Harapan Desa Sukamaju, bersama - sama mendirikan sampah yang bernama Bank Sampah Sukamaju Sejahtera. Di dalam pelaksanaan dan awal mula berdirinya bank sampah Sukamaju Sejahtera ini banyak hambatan - hambatan juga bentuk penolakan dari masyarakat Desa Sukamaju itu sendiri, hal ini karna masih minimnya serta rendahnya kesadaran masyarakat desa Sukamaju akan pentingnya menjaga kebersihan lingkungan memlalui program pengelolaan sampah yang di buat bank sampah Sukamaju Sejahtera dengan tujuan agar desa Sukamaju dapat terbebas dari masalah - masalah terhadap sampah yang selama ini mereka rasakan.

\section{LANDASAN TEORI Konsep Pendidikan Luar Sekolah}

Beberapa ahli mendeinisikan Pendidikan Luar Sekolah dengan segala aspeknya. Berbagai definisi tersebut dimaksudkan sebagai upaya untuk menjelaskan batasan dan ciri - ciri pendidikan luar sekolah terutama dengan pendidikan persekolahan. Definisi pendidikan luar sekolah menurut Coombs dalam Sudjana (2004: 22) adalah: 
"Setiap kegiatanterorganisasi dan sistematis, diluar sistem persekolahan yang mapan, dilakukan secara mandiri atau merupakan bagian penting dari kegiatan yang lebih luas, yang sengaja dilakukan unutk melayani peserta didik tertentu dalam mencapai tujuan belajarnya."

\section{Konsep Kesadaran}

Kesadaran diri adalah pemahaman terhadap kekhasan fisik, kepribadian, watak, dan temperamenya: mengenal bakat-bakat alamiah yang dimilikinya dan punya gambaran atau konsep yang jelas tentang diri sendiri dengan segala kekuatan dan kelemahanya, Antonius (dalam Malikah, 2013).

Kesadaran adalah sikap seseorang yang secara sukarela menanti semua peraturan dan sadar akan tugas dan tanggung jawabnya, Hasibuan (2012:193).

Soekanto (2002) mengatakan bahwa terdapat empat indikator kesadaran yang masingmasing merupakan suatu tahapan bagi tahapan berikutnya dan menunjuk pada kegiatan tertentu, mulai dari yang terendah sampai tinggi, antara lain:
a. Pengetahuan
b. Pemahaman
c. Sikap, dan
d. Pola perilaku (tindakan).

\section{Konsep masyarakat}

Sedangkan menurut Selo Sumardjan dalam Soerjono Soekanto (2002: 24) menyatakn bahwa masyarakat adalah orang-orang yang hidup bersama, yang menghasilkan kebudayaan.

Menurut Ralph Linton dalam Soerjono Soekanto (2002: 24) berpendapat bahwa masyarakat merupakan setiap kelompok manusia yang telah hidup dan bekerja cukup lama sehingga mereka dapat mengatur diri mereka dan menganggap diri mereka sebagai suatu kesatuan social dengan bata-batas yang dirumuskan dengan jelas.

Menurut Maclever dan Page dalam Soerjono Soekanto (2002: 24) menyatakan bahwa masyarakat ialah suatu sistem dari kebiasaan dan tata cara, dari wewenang dan kerjasama antara berbagai kelompok dan penggolongan, pengawasan tingkah laku serta kebebasan-kebebasan manuisa. Keseluruhan yang selalu berubah ibi kita namakan masyarakat. Masyarakat merupakan jalinan hubungan sosial. Dan masyarakat selalu berubah.

Menurut Soerjono Soekanto (2002: 24) manyatakan bahwa pada dasarnya masyarakat pada dasarnya memiliki isi yang sama dan mencakup beberapa unsur sebagai berikut:

a. Manusia yang hidup bersama.

b. Bercampur dalam waktu yang cukup lama.

c. Mereka sadar behwa mereka merupakan suatu kesatuan.

d. Mereka merupakan suatu sistem kehidupan bersama. 


\section{Konsep Sampah}

Kamus Lingkungan (1994) dalam Basriyanta (2007). Sampah adalah bahan sisa, baik bahan - bahan yang sudah tidak terpakai lagi maupun bahan yang sudah diambil bagian utamanya atau yang diinginkanya dari segi ekonomis.

Dari seluruh pengertian diatas, maka dapat penulis simpulkan bahwa apa yang disebut sebagai sampah adalah segala bentuk barang yang sudah tidak lagi memiliki nilai jual atau nilai ekonomis untuk digunakan atau merupakan barang buangan atau sisa dari hasil kegiatan aktifitas atau kegiatan manusia yang dapat berbentuk benda padat maupun benda semi padat. Sehingga sampah harus dibuang karna tidak mempunyai guna lagi, karna sudah tidak memiliki nilai ekonomis itulah kadang yang membuat sampah selalu dipandang sebelah mata oleh masyarakat sehingga mereka dengan sengaja membuangnya secara sembarangan ataupun tidak pada tempatnya, yang apabila dibiarkan secara terus menerus dan tidak ditangani dengan cara yang benar maka akan menimbulkan masalah - masalah yang terjadi pada lingkungan. Maka dari itu alangkah baiknya sampah dikelola dengan cara baik dan benar dengan pemanfaatan Reduce, Reuse dan juga Recycle (3R) agar bias kembali memiliki nilai ekonomis dan bahkan dapat digunakan kembali.

\section{Konsep Bank Sampah}

Manurut Kamus Besar Bahasa Indonesia (2008), bank sampah adalah sistem pengelolaan sampah kolektif yang menyerupai rekening bank untuk menampung, memilah, dan menyalurkan sampah bernilai ekonomis pada pasar dengan melibatkan masyarakat.

Menurut permen LH RI No 13 Tahun 2012 Bank Sampah adalah tempat pemilihan dan pengumpulan sampah yang dapat di duar ulang dan atau digunakan ulang yang memiliki nilai ekonomi.

Sementara itu pengertian bank sampah menurut Suwerda (2012: 22) yaitu suatu tempat dimana terdapat kegiatan pelayanan terhadap penabung sampah yang dilakukan oleh teller bank sampah.

Bank sampah itu sendiri merupakan semacam tempat pengaplikasian sistem 3R di masyarakat untuk mengurangi jumlah sampah kemudian mengumpulkan berbagai macam jenis sampah tersebut untuk dilakukan pemilahan dan pemisahan lalu digolongkan berdasarkan bobot, jenis sampah, harga jual dll. Sampah yang sudah di pilah dan pisah tersebut nantinya akan dikumpulkan dalam jangka waktu dan jumlah tertentu yang nantinya akan di lakukan proses penjualan, penggunaan kembali, atau bahkan melalui proses daur ulang agar bisa memiliki nilai ekonomi atau kegunaan kembali. Pada dasarnya bank sampah hampir sama dengan bank penyimpanan uang pada umumnya, yang membedakanya adalah disini nasabah bank tidak menyetorkan dalam bentuk uang, melainkan dalam bentuk sampah yang mereka kumpulkan dari aktivitas mereka seharihari baik itu sampah rumah tangga maupun sampah dari limbah-limbah yang sudah tidak terpakai. 


\section{METODE}

Pendekatan penelitian yang digunakan dalam penelitian ini adalah pendekatan kualitatif dan metode penelitian yang dipergunakan adalah metode adalah pendekatan deskriptif kualitatif dan akan menghasilkan data deskriptif berupa kata-kata tertulis atau lisan dari orang-orang juga dari perilaku yang diamati.

Maka dari penjelasan diatas, penulis memilih untuk menggunakn pendekatan ini dengan harapan penulis akan dapat menghasilkan data yang deksriptif guna mengungkapkan sebab dan proses terjadinya. Lokasi atau tempat penelitian dilakukan di bank sampah Sukamaju Sejahtera yang berada di desa Sukamaju RT 04 RW 06, Kecamatan Padalarang, Kabupaten Bandung Barat. Pemilihin lokasi dipilih karena merupakan satu-satunya bank sampah yang dibangun secara mandiri oleh Ketua RW 06 desa Sukamaju, beserta PKH, dan juga dibantu oleh karang taruna desa yang berada di Kecamatan Padalarang. Dimana bank sampah ini secara bertahap dapat mengubah perilaku masyarakat dalam menjaga kebersihan lingkungan, hal inilah yang membuat rasa ingin tahu penulis tergugah, dan juga merasa ingin tahu lebih dalam dari kegiatan bank sampah Sukamaju Sejahtera ini.

\section{HASIL DAN PEMBAHASAN}

\section{Perencanaan program dalam mengelola bank sampah Sukamaju Sejahtera di desa Sukamaju}

Sampah dapat dibagi menjadi dua macam bagian, yaitu sampah yang mudah hancur atau sampah yang mudah diuraikan oleh alam yang biasa disebut dengan sampah organik, contohnya seperti sampah sisa-sisa sayuran dan lain-lain, dan juga sampah yang tidak mudah hancur atau tidak bisa diuraikan oleh alam yang biasa disebut dengan sampah anorganik, contohnya seperti sampah yang berasal dari bahan plastik, kaca, kaleng dan sebagainya. Hal ini tentu mendapatkan sorotan khusus dimana dengan banyaknya jumlah pertumbuhan penduduk suatu daerah, otomotis sampah yang dihasilkan juga ikut meningkat. Sama dengan desa Sukamaju dimana persoalan ini muncul akibat masih banyak yang sering membuang sampah secara sembarangan dan tidak pada tempatnya.

Meski sebagian masyarakat di desa Sukamaju sudah memiliki kesadaran akan kebersihan lingkungan, namun masyarakat masih belum memiliki kesadaran akan menjaga kebersihan lingkungan secara menyeluruh dan merata. Karena masih adanya masyarakat yang memiliki rendahnya kesadaran akan kebersihan lingkungan tadi, maka hal yang dapat ditimbulkan adalah dengan adanya pencemaran lingkungan yang diakibatkan dari sampah, dan lokasi pencemaran tersebut antara lain berada di selokan-selokan yang tersumbat karena sampah sehingga saat musim penghujan tiba menimbulkan banjir, dan kerap menimbulkan penyakit Demam Berdarah Dengue (DBD) karena sampah genangan air yang kotor merupakan sarang bagi nyamuk utnuk berkembang biak, lalu masih banyaknya sampah yang dibuang dan ditumpuk secara sembarangan di pinggir-pinggir jalan yang menimbulkan pencemaran lingkungan, dimana lingkungan menjadi kurang sedap dipandang dan bersta dibawah jembatan yang ada di sekitar perumahaan warga desa Sukamaju.

Selain dari masih rendahnya kesadaran yang dimiliki, hal ini juga diperparah dengan fasilitas Tempat Pembuangan sampah Sementara (TPS) yang hanya berjumlah satu buah tempat saja yang dijadikan tempat pembuangan sampah di desa sukamaju, dimana TPS ini menurut masyarakat masih dirasa jauh dari layak untuk menampung jumlah sampah yang ada di desa Sukamaju. 
Oleh karena itu Ketua RW 06 desa Sukamaju pun memiliki program yang dirasa dapat membantu masyarakat untuk meningkatkan kesadaran akan menjaga kebersihan lingkungan seperti kegiatan kerja bakti yang dilaksanakan selama enam bulan sekali. Selain itu memiliki program baru yang dirasa tepat untuk mengurangi jumlah volume sampah yang ada di desa Sukamaju dengan merenacanakan pendirian program bank sampah.

Selain itu bapak Toni Permana selaku Ketua RW 06 yang di bantu oleh para pengurus maupun anggota dari PKH serta Karang Taruna Bhakti Persada 06 secara mandiri mengusulkan dan membuat suatu wadah bagi masyarakat supaya bisa merubah pola fikir dan juga perilaku masyarakat desa Sukamaju untuk menjaga kebersihan lingkungan yang terbebas dari sampah. Dan dana yang digunakan untuk program tersebut menggunakan dana pribadi Ketua RW06, serta swadaya sumbangan dari para pengurus serta anggota Karang Taruna Bhakti Persada RW 06 dan PKH desa Sukamaju, tanpa ada sepeserpun bantuan dari pihak pemerintah.

Dan tepat pada bulan Mei Tahun 2017 oleh Ketua RW 06 yang menjabat saat itu, yakni bapak Toni Permana yang di bantu oleh para pengurus maupun anggota dari PKH serta Karang Taruna Bhakti Persada 06, melakukan izin pendirian program kepada Ketua RW, RT 06, tokoh masyarakat serta masyarakat desa Sukamaju dan kemudian tercetuslah bank sampah yang bernama Bank Sampah Sukamaju Sejahtera. Yang beranggotakan sebanyak 30 orang, yang berisi para pengurus dan anggota dari Karang Taruna Bhakti Persada RW 06 dan PKH desa Sukamaju sebagai anggota awal dari Bank Sampah Sukamaju Sejahtera. Dimana dalam mendirikan bank sampah Sukamaju Sejahtera ini dilandasi dari bentuk keprihatinan bapak Toni Permana selaku ketua RW 06 desa Sukamaju, terhadap tingkat kesadaran masyarakat desa Sukamaju dalam menjaga kebersihan lingkungan yang masih cukup rendah. Sehingga saat musim penghujan tiba, desa Sukamaju ini selalu mengalami banjir akibat penyumbatan sampah di tiap - tiap selokan di sekitar pemukiman warga.

\section{Proses pengelolaan bank sampah Sukamaju Sejahtera untuk menumbuhkan kesadaran masyarakat untuk tidak membuang sampah sembarangan}

Dalam merealisasikan program bank sampah yang dicetuskan oleh bapak Toni Permana yang di bantu oleh para pengurus maupun anggota dari PKH serta Karang Taruna Bhakti Persada 06, dilakukan sosialisasi mengenai bank sampah kepada masyarakat di desa Sukamaju dengan berbagai cara. Seperti, bapak Toni Permana selaku Ketua RW 06 desa Sukamaju, mengajak sebagian para pengurus maupun anggota dari PKH serta Karang Taruna Bhakti Persada 06 untuk melakukan studi banding guna mendapatkan ilmu dan pemahaman mengenai bank sampah ke bank sampah yang sudah terlebih dahulu berdiri di daerah Cimahi. Studi banding ini bertujuan untuk nantinya para anggota awal bank sampah Sukamaju Sejahtera yang beranggotakan para pengurus dan anggota dari PKH serta Karang Taruna Bhakti Persada 06 ini dapat memeberikan edukasi mengenai apa itu bank sampah, cara memilah sampah yang baik dan benar, cara menjadikan sampah menjadi barang yang berguna dan memiliki nilai ekonomi dll kepada masyarakat di desa Sukamaju.

Selain itu, dilakukan dengan cara lain seperti dengan menggunakan penedakatan secara langsung atau face to face terhadap masyarakat desa Sukamaju dilapangan, maupun dengan mendatangi langsung rumah-rumah dari masyarakat desa Sukamaju untuk melakukan penyuluhan mengenai bank sampah itu sendiri. Kemudian dengan melakukan cara membentuk 30 orang nasabah awal dari bank sampah Sukamaju Sejahtera yang beranggotakan para pengurus beserta anggota dari PKH juga Karang Taruna Bhakti Persada RW06 desa Sukamaju. Pembentukan nasabah awal ini bertujuan untuk memancing minat dari masyarakat Sukamaju agar supaya ikut menjadi anggota nasabah dari bank sampah Sukamaju Sejahtera. 
Sosialisasi ini dilakukan baik secara langsung terjun kelapangan maupun dengan cara mengumpulkan masyarakat pada saat perkumpulan atau rapat RT desa Sukamaju berlangsung. Namun tentu dalam menyampaikan sosialisasi banyak pula respon dari masyarakat mengenai bank sampah itu sendiri. Karena hal ini tidak sebanding lurus dengan pola fikir dan perilaku yang dicerminkan oleh masyarakat desa Sukamaju dalam menjaga kebersihan lingkungan, sehingga dalam proses untuk mewujudkan desa Sukamaju yang terbebas dari sampah dirasakan sangat sulit dimana pada tahap awal pendirian bank sampah Sukamaju Sejahtera ini memiliki beragam respon dari masyarakat, ada yang menerima ada pula yang bahkan menolaknya.

Namun seiring berjalanya waktu bapak Toni Permana yang di bantu oleh para pengurus maupun anggota dari PKH serta Karang Taruna Bhakti Persada 06, tetap sabar dan meyakini bahwa suatu saat masyarakat desa Sukamaju akan dapat menerima program bank sampah Sukamaju Sejahtera dan juga dapat sadar dalam menjaga kebersihan lingkungan. Dengan ketekunan dan juga kesabaran inilah, lambat laun jumlah anggota dari nasabah bank sampah Sukamaju Sejahtera yang semula berjumlah 30 orang anggota yang merupakan para pengurus beserta anggota dari PKH juga Karang Taruna Bhakti Persada RW06 desa Sukamaju, kini mengalami kenaikan yang bertahap dan telah telah bertambah menjadi 186 orang anggota masyarakat desa Sukamaju yang terdaftar sebagai nasabah dari Bank Sampah Sukamaju Sejahtera. Dengan adanya peningkatan tersebut kini bank sampah Sukamaju Sejahtera ini telah mendapatkan kepercayaan juga antusias dari masyarakat desa Sukamaju yang sangat baik, bahkan hingga mendapatkan perhatian dari RW lainya di sekitar desa Sukamaju.

\section{Hasil pengelolaan bank sampah Sukamaju Sejahtera dalam menciptakan lingkungan yang terbebas dari sampah}

Dari kesimpulan hasil wawancara mengenai respon masyarakat sebelum berdirinya program Bank Sampah Sukamaju Sejahtera, dapat disimpulkan masalah utama yang timbul mengenai lingkungan desa Sukamaju adalah masih banyaknya masyarakat yang masih belum sadar dan tahu akan pentingya menjaga kebersihan lingkungan, terutama dari sampah. Hal ini diperparah dengan masih yang sering membuang sampah secara sembarangan, baik diselokan-selokan, pinggir jalan dan lain-lain, sehingga menjadikan lingkungan desa Sukamaju menjadi tercemar, kotor dan dipenuhi sampah yang berserakan. Namun setelah berdirinya program Bank Sampah Sukamaju Sejahtera, masyarakat serta nasabah merasa terbantu karna bank sampah sedikit menjadi bersih, dan membantu mengurangi jumlah sampah yang ada di lingkungan masyarakat sehingga keadaanya cukup berbeda dengan keadaan sebelumnya. Bank sampah dirasa masyarakat dapat membantu dalam meningkatkan kesadaran masyarakat untuk menjaga kebersihan lingkungan di desa Sukamaju, bahkan menjadi malu dan takut untuk membuang sampah secara sembarangan.

Bank sampah dirasa dapat memberikan pemahaman juga memberikan ilmu untuk memisahkan sampah, terutama sampah jenis plastik, dan lebih memilih untuk menyetorkanya ketimbang dibuang begitu saja. Bank sampah juga dirasa dapat menjadi solusi yang sudah cukup tepat untuk menjaga kebersihan lingkungan di desa Sukamaju, karna menurut masyarakat belum ada program yang dapat membantu masyarakat untuk dapat mengatasi perilaku dan mindset mengenai masalah sampah seperti program bank sampah Sukamaju Sejahtera ini. Dan harapan dari masyarakat serta nasabah untuk Bank Sampah Sukamaju Sejahtera sendiri agar kedepanya bank sampah dapat meningkatkan lagi kinerja para pengelola dengan menambahkan jumlah pengelola bank sampah, terus melakukan inovasi dalam rangka mengembangkan program yang telah dijalankan sebelumnya. Selain itu masyarakat serta nasabah bank sampah berharap dengan adanya 
Bank Sampah Sukamaju Sejahtera ini lingkungan desa Sukamaju kedepanya supaya bersih dan terbebas dari sampah yang dibuang sembarangan agar tidak lagi terkena bencana banjir seperti sebelumnya.

\section{KESIMPULAN}

Berdasarkan hasil penelitian, untuk menjawab pertanyaan-pertanyaan yang telah dirumuskan pada BAB I, dapat dikatakan bahwa program Bank Sampah Sukamaju Sejahtera ini telah berhasil meningkatkan kesadaran masyarakat dalam menjaga kebersihan lingkungan. Hal ini dibuktikan ditunjukkan seperti kesimpulan sebagai berikut:

1. Kegiatan program Bank Sampah Sukamaju Sejahtera ini diselenggarakan sebagai upaya untuk meningkatkan kesadaran masyarakat agar tidak membuang sampah sembarangan, dan juga sebagai upaya dalam menjaga kebersihan lingkungan terhadap perilaku serta kesadaran masyarakat desa Sukamaju yang dinilai masih rendah dalam membuang sampah sembarangan. Di samping itu kegiatan ini akan menimbulkan minat bagi masyarakat untuk melakukan kegiatan positif yang dinilai dapat menjaga lingkungan agar terbebas dari sampah. Persiapan dan juga teknis pelaksanaan kegiatan program bank sampah ini dilakukan dengan mengidentifikasi tingkat kesadaran masyarakat desa Sukamaju dalam menjaga kebersihan lingkungan, serta melihat aspek dari banyaknya keluhan masyarakat mengenai sampah di desa Sukamaju.

2. Program bank sampah ini juga berdampak positif bagi masyarakat, terutama dalam hal:

a. Membangkitkan minat masyarakat dalam menjaga kebersihan lingkungan

b. Meningkatkan kesadaran masyarakat untuk menjaga lingkungan agar terbebas dari masalah sampah

c. Memberikan pemahaman serta ilmu mengenai bagaimana caranya untuk mengelola sampah dengan cara yang baik dan benar

d. Membekali masyarakat dengan program pelatihan kerajinan dari sampah agar kedepanya masyarakat memiliki keahlian dalam mengolah sampah menjadi barang yang bernilai ekonomi

e. Memberikan penghasilan tambahan

3. Aspek permodalan dan pemasaran hasil kerajinan dinilai merupakan kendala utama dalam pelaksanaan program bank sampah ini. Minimnya bantuan mengenai sumber modal usaha dan juga belum adanya bantuan terhadap pemasaran hasil kerajinan inilah, nantinya akan menyebabkan kinerja dari program bank untuk meningkatkan serta mengembangkan potensi yang dimiliki akan menjadi terbatasi dan terhambat.

\section{DAFTAR PUSTAKA}

Baron, Robert, A,. \& Bryne. D. (2012) Psikologi Sosial Jilid 2. Jakarta. Erlangga

Basriyanta. 2007. Memanen Sampah. Yogyakarta: Kanisius

Damanhuri, Erni dan Tri Padmi. 2010. Diktat Kuliah Pengelolaan Sampah, Institut Teknologi Bandung. Bandung

Hashibuan, Malayu S. P 2012, Manajemen Sumber Daya Manusia cetakan keenam belas, Jakarta: PT. Bumi Aksara 
270 Rahmadani, Upaya Menumbuhkan Kesadaran Masyarakat Dalam Menjaga Kebersihan Lingkungan Melalui Pengelolaan Bank Sampah

Kamil. M. (2012). Model Pendidikan dan Pelatihan (Konsep dan Aplikasi). Bandung: Alfabeta

Kastaman, R dan Kramadibrata, A. 2007. Sistem Pengelolaan Reaktor Sampah Terpadu Silarsatu. Humaniora, Bandung.

Malikah (2013) Kesadaran Diri Proses Pembentukan Karakter Islam. Jurnal Al-Ulum Vol 13 Nomor 1 Juni 2013. Diakses pada 16 Agustus 2019, Dari Journal.iaingorontalo.ac.id/index.php/au/article/view/94/79

Mallongi, A. Dan Saleh, M., 2015. Pengelolaan limbah Padat Perkotaan. Makassar: Penerbit WR

Mulia, R. M. 2005. Kesehatan Lingkungan. Yogyakarta, Graha Ilmu

Notoatmojo, Soekidjo, 2003, Pengembangan Sumber Daya Manusia, Jakarta. PT Rineka Cipta

Peraturan Menteri Negara Lingkungan Hidup Republik Indonesia Nomor 13 Tahun 2012. Tentang Pedoman Pelaksanaan Reduce, Reuse Dan

Recycle Melalui Bank Sampah. Jakarta: Menteri Negara Lingkungan Hidup Republik Indonesia

Sudjana, Djudju. 2004. Pendidikan Non Formal. Bandung: Fallah Production

Sudjana, Djudju. 2006 Evaluasi Program Pendidikan Luar Sekolah (Untuk Pendidikan Nonformal Dan Pengembangan Sumber Daya Manusia). Bandung: Fallah Production

Sugiyono, 2017. Metode Penelitian Pendidikan (Pendekatan Kuantitatif, Kualitatif dan R\&D). Bandung . Alfabeta

Suyoto, Bagong. 2008. Fenomena Gerakan Mengelola Sampah. Jakarta. PT Prima Media.

Suwerda, B. 2012. Bank Sampah: Kajian Teori dan Penerapanya.Yogyakarta: Pustaka Rihamma

Soekanto, Soerjono, 2002, Teori peranan. Jakarta, Bumi Aksara 